\title{
"Investment activities of banks, insurance companies, and non-government pension funds in Ukraine"
}

\begin{tabular}{|c|c|}
\hline \multirow{6}{*}{ AUTHORS } & Serhiy Reverchuk (D) https://orcid.org/0000-0002-6517-8892 \\
\hline & Olga Vovchak (D) https://orcid.org/0000-0002-8858-5386 \\
\hline & Tetyana Yavorska (D http://orcid.org/0000-0001-7557-5683 \\
\hline & Lyudmyla Voytovych (D) https://orcid.org/0000-0003-4514-7770 \\
\hline & Olesya Irshak (D https://orcid.org/0000-0002-1536-8161 \\
\hline & R http://www.researcherid.com/rid/D-5950-2019 \\
\hline ARTICLE INFO & $\begin{array}{l}\text { Serhiy Reverchuk, Olga Vovchak, Tetyana Yavorska, Lyudmyla Voytovych and } \\
\text { Olesya Irshak (2020). Investment activities of banks, insurance companies, and } \\
\text { non-government pension funds in Ukraine. Investment Management and } \\
\text { Financial Innovations, 17(2), 353-363. doi:10.21511/imfi.17(2).2020.27 }\end{array}$ \\
\hline DOI & http://dx.doi.org/10.21511/imfi.17(2).2020.27 \\
\hline RELEASED ON & Friday, 03 July 2020 \\
\hline RECEIVED ON & Friday, 29 May 2020 \\
\hline \multirow[t]{2}{*}{ ACCEPTED ON } & Thursday, 25 June 2020 \\
\hline & $(\mathrm{cc}) \mathrm{EY}$ \\
\hline LICENSE & $\begin{array}{l}\text { This work is licensed under a Creative Commons Attribution } 4.0 \text { International } \\
\text { License }\end{array}$ \\
\hline JOURNAL & "Investment Management and Financial Innovations" \\
\hline ISSN PRINT & $1810-4967$ \\
\hline ISSN ONLINE & $1812-9358$ \\
\hline PUBLISHER & LLC "Consulting Publishing Company "Business Perspectives" \\
\hline FOUNDER & LLC "Consulting Publishing Company "Business Perspectives" \\
\hline
\end{tabular}

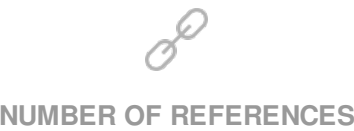

25
NUMBER OF FIGURES

3

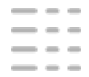

NUMBER OF TABLES

2

(C) The author(s) 2023. This publication is an open access article. 


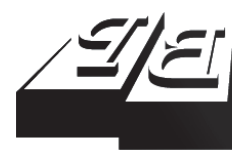

BUSINESS PERSPECTIVES

(2)

LLC "CPC "Business Perspectives" Hryhorii Skovoroda lane, 10, Sumy, 40022, Ukraine www.businessperspectives.org

Received on: $29^{\text {th }}$ of May, 2020 Accepted on: $25^{\text {th }}$ of June, 2020 Published on: $3^{\text {rd }}$ of July, 2020

( ) Serhiy Reverchuk, Olga Vovchak, Tetyana Yavorska, Lyudmyla

Voytovych, Olesya Irshak, 2020

Serhiy Reverchuk, Doctor of Economics, Professor, Head of Department of Banking and Insurance Business, Ivan Franko National University of Lviv, Ukraine.

Olga Vovchak, Doctor of Economics, Professor, Head of Department of Finance, Banking and Insurance, University of Banking of the National Bank of Ukraine, Ukraine.

Tetyana Yavorska, Doctor of Economics, Professor, Professor of Department of Banking and Insurance Business, Ivan Franko National University of Lviv, Ukraine.

Lyudmyla Voytovych, Ph.D. in Economics, Associate Professor Department of Banking and Insurance Business, Ivan Franko National University of Lviv, Ukraine. (Corresponding author)

Olesya Irshak, Ph.D. in Economics, Associate Professor, Department of Banking and Insurance Business, Ivan Franko National University of Lviv, Ukraine.
Serhiy Reverchuk (Ukraine), Olga Vovchak (Ukraine), Tetyana Yavorska (Ukraine), Lyudmyla Voytovych (Ukraine), Olesya Irshak (Ukraine)

\section{INVESTMENT ACTIVITIES OF BANKS, INSURANCE COMPANIES, AND NON-GOVERNMENT PENSION FUNDS IN UKRAINE}

\begin{abstract}
Successful solution of main problems and contradictions in the development of financial intermediaries' investment activities largely depends on their timely detection, which is facilitated using trend forecasting models. The research aims to determine the current investment potential of financial intermediaries in the Ukrainian economy, find out the features and general problems, and identify the main perspective directions for the development of their investment activities. The article reveals the main internal and external factors and the source of development and inhibition of Ukrainian banks' investment activities, insurance companies, and non-government pension funds. Based on the analysis, the investment structure patterns for key groups of financial intermediaries were defined. The forecast of their investments for 2020-2022 allows comparing the investment activities of selected financial intermediaries and offering conditions for the intensification of investment activities for banks (formation of reserves and cash flows control), insurance companies (to develop investment strategies), and private pension funds (to allow investing funds in collateralized government debt securities).
\end{abstract}

\section{Keywords}

investments, financial intermediaries, commercial banks, insurance companies, equity, securities, nongovernment pension funds, pension contributions

\section{JEL Classification $\quad$ G17, G22, G23, G24}

\section{INTRODUCTION}

The largest investors in the world economy are financial intermediaries, and their investments are a prerequisite for the development of the modern market economy. Banks, insurance companies (ICs) and non-government pension funds (NPFs), which, on the one hand, belong to powerful institutional investors, and, on the other hand, offer appropriate financial services and thus affect the investment climate in the country, are major participants on the investment market. The investment activity of financial intermediaries is an important area of their economic and financial activities. Nowadays, banks, ICs, and NPFs make real and financial investments. The real investment is an investment in real assets. It is an investment into their own activities, such as their fixed assets, new financial services, opening branches, and education and training of their employees; they also invest into other activities (by directing them to set up businesses or participate in their activities (other than buying shares)). Such businesses can form the proper infrastructure. Life insurance companies have the right to use credit investment instruments: to provide loans to insurers within the redemption amount and provide long-term housing finance. 
Financial investments of selected financial intermediaries are investments in various financial instruments that are strategic (involving the acquisition of a controlling or significant stake to implement strategic objectives) and portfolios (which aim to obtain current income or increase invested capital). Financial investments are a priority area of investment in the practical activity of many financial intermediaries, including foreign ones, and involve investments in securities, the authorized capital of economic entities, and deposit investments. In this regard, the question of investment activity valuation and the instruments mentioned above used by domestic commercial banks, IC, and NPF becomes relevant. The combination of real and financial investments forms an investment portfolio that should maximize profitability and minimize risks and ensure the return on investment.

\section{THEORETICAL BASIS}

Several authors have been studying the investment activity of financial intermediaries in Ukraine. The studies of these authors were local, i.e., they dealt with an individual financial intermediary's investment activity. Thus, Kuzheliev (2016), studying the investment activity of banks, indicates that the stock and bond market currently cannot provide the necessary amount of investment in the non-financial sector of the economy and therefore to activate the activity of banks on the market, it is appropriate to implement measures to provide financial flexibility for decision-making. Liaw (2012), focused on the study of banking investments and the new investment banking structure, which will include financial holding companies, full-service, and boutique investment banks who will deal with the securitization of assets: the conversion of income flows into new investment funds. Onyshchenko (2018), researching the issues of managing the investment activity of banks, proves that despite the difficulties in the activity, banks still seek to invest in securities, and also indicates that it would be advisable to allow portfolio investments in international markets on the first stage and having gained some experience, investors will be able to more actively and professionally develop the domestic stock market. Gordillo (2019), studying corporate and investment banking, focused on financing enterprises and corporations' development and meeting their investment needs. Yavorska (2012), analyzing financial assets in which insurance companies can invest, identifies the main sources of investment and proposes to use their own funds and funds of insurance reserves of insurance companies for investing purposes. Della Croce (2011) argued that institutional investors - insurance companies and mutual funds - have the potential to play a more active role in bridging the infrastructure gap. Rekunenko and Chorna (2017), examining the issues of investing, examined that insurance companies are mainly engaged in their own insurance activities and much less in investment, and this is influenced by several restrictions, including political and economic instability in the country, limited list of investment instruments, in which the insurance companies could invest. Shaliyevska (2018, p. 120), examining the impact of destructive factors on the development of non-state pension insurance in Ukraine, identifies the risks of insignificant attraction of pension contributions for diversification of pension assets into profitable financial instruments.

However, financial intermediaries are now a powerful investment sector, with commercial banks, insurance companies, and private pension funds as the main players. Therefore, to identify problems and prospects for the development of the Ukrainian economy, a comprehensive study of the investment activity of this sector of the financial economy is needed.

In accordance with this research problem, the following scientific hypotheses are grounded in the article:

- crucial activity of banks as investor institutions in the financial market can have a decisive impact on the investment climate in Ukraine;

- under conditions to increase the efficiency of using the investment potential of banks, the country's investment attractiveness and the economy as a whole increase;

- if ICs are powerful institutional investors and 
provide insurance protection to economic entities from possible losses, they affect the country's investment climate in the country;

- under the condition of effective state regulation and proper investment attractiveness of the country, region, and economic entities, the IC's active investment activity is possible;

- while accumulating pension contributions, NPFs invest in financial instruments, the definition of which allows for outlining the potential of this financial intermediary.

The activities of banking institutions are the key to the stability of the economic system of any state. Considering that the attractiveness of the domestic economy at the international level is rather low, interest in Ukrainian banks as potential investors is growing. Investment cooperation is a priority in the interaction of domestic banks with international organizations. In the authors' view, credit, deposit, and investment activities can be considered banks' main activities. The authors will take a closer look at the investment activity of banks, which involves transforming their investment potential into investment income.

Banking institutions on the financial investment market act as intermediaries, custodians, traders, investors, issuers and consultants. When investing in the stock market, banks have the following main goals: to maximize profits, generate funds, and increase exposure and provide liquidity (Kuzheliev, 2016). Each bank is eager to take a competitive position in the securities market. Its peculiarity is that it is a kind of indicator of determining the process of investing in the stock market.

The main factors influencing the investment activity of the bank include GDP level; inflation rate; population income, the level of corruption in the country, the level of economic development in the country; stability of the national currency, volume of foreign investments, political component, events in the East of the state, etc.

The authors will analyze the volume of investments of Ukrainian banks from 2009 to 2018. First of all, it should be noted that for the period up to 2009 , the number of banks was 182 , whereas, at the beginning of 2019 (January 1, 2019), there were only 77 banks, which is a positive trend. For further analysis, we selected the three indicators with the highest share in the investment activity of banks: real estate investments, investments in subsidiaries and associates, and investments in securities.

Table 1 shows that securities made the largest share in the total volume of investments of Ukrainian banks. Their volume increased from UAH 39.335 million in 2009 to UAH 480.608 million at the end of 2018, which is by UAH 441.273 million more. Banks are investing heavily in real estate. Over the period 2009-2016, real estate investments increased and at the beginning of 2017 reached UAH 20.291 million. From 2017 to 2018, there was a downward trend, and at the beginning of 2019, the volume of investments was UAH 16.585 million. Banks, having made investments in subsidiaries and associates by 2014, were actively investing and showing unconditional growth (in 2009 - UAH 1.285 million, whereas in 2014 - UAH 2.070 million, which was UAH 785 million more). Starting in 2015 and up to the present, statistics show much smaller amounts of banking investment into this area. At the end of 2018, the volume of bank investments amounted to UAH 457 million, which is $35.56 \%$ less than in 2009 .

A much higher level of risk than in other activities and the stock market's volatility appear to be the inhibiting factors of banks' investment activity, which can lead to significant losses.

Also, banking institutions need to be capitalized today, which is a vital task for the vast majority of them (Onyshchenko, 2018). The development of banks' investment activity is hindered by the lack of an appropriate legal framework governing the relations of participants in the investment process. However, another problem arising in the process of banking investment activity is the unfavorable investment climate in Ukraine. To avoid all these shortcomings in the investment activity of banks, it is necessary to: establish cooperation between large banks, conduct a constant analysis of the effectiveness of their investments, and legally define the mechanism for stimulating and making investments in the domestic economy. 
Table 1. Main indicators of financial intermediaries functioning in Ukraine, 2009-2018

Source: Created by the authors of the article based on statistics of Ukraine (official data of insurance companies in 2012-2018, official activity data of banks in 2009-2018, results of the development of the private pension system in 2011-2018)

\begin{tabular}{|c|c|c|c|c|c|c|c|c|c|c|}
\hline \multicolumn{11}{|c|}{ Banks } \\
\hline Indicators & 2009 & 2010 & 2011 & 2012 & 2013 & 2014 & 2015 & 2016 & 2017 & 2018 \\
\hline Number of banks & 182 & 176 & 176 & 176 & 180 & 163 & 117 & 96 & 82 & 77 \\
\hline $\begin{array}{l}\text { Assets of banks, UAH } \\
\text { million }\end{array}$ & 880302 & 942088 & 1054280 & 1127192 & 1278095 & 1316852 & 1254385 & 1256299 & 1336358 & 1360764 \\
\hline $\begin{array}{l}\text { Investment volume of } \\
\text { banks, includes, UAH } \\
\text { million: }\end{array}$ & 41930 & 89351 & 97155 & 112642 & 158538 & 190026 & 221911 & 353451 & 442935 & 497650 \\
\hline Bank deposits & 1310 & 4215 & 7504 & 13982 & 17486 & 19028 & 19315 & 20291 & 16318 & 16585 \\
\hline $\begin{array}{l}\text { Investment volume to } \\
\text { the subsidiaries and } \\
\text { associates }\end{array}$ & 1285 & 1577 & 1932 & 2320 & 2765 & 2070 & 1076 & 887 & 827 & 457 \\
\hline Securities & 39335 & 83559 & 87719 & 96340 & 138287 & 168928 & 201520 & 332273 & 425790 & 480608 \\
\hline $\begin{array}{l}\text { Investment volume on the } \\
\text { one bank, UAH million }\end{array}$ & 230,38 & 507,68 & 552,02 & 640,01 & 880,77 & 1165,80 & 1896,68 & 3681,78 & 5401,65 & 6462,99 \\
\hline \multicolumn{11}{|c|}{ Insurance companies } \\
\hline Number of IC & 450 & 456 & 442 & 414 & 407 & 382 & 361 & 310 & 294 & 281 \\
\hline Assets of IC, UAH million & 41970,1 & 45234,6 & 48122,7 & 56224,7 & 66387,5 & 70261,2 & 60729,1 & 56075,6 & 57381,0 & 63493,3 \\
\hline $\begin{array}{l}\text { Investment volume of IC, } \\
\text { includes, UAH million: }\end{array}$ & 19081,6 & 21966,3 & 23505,6 & 44963,0 & 32677,8 & 33856,6 & 30137,8 & 28656,0 & 29258,3 & 32266,2 \\
\hline Bank deposits & 5926,4 & 6464,6 & 8250,0 & 8746,1 & 9296,4 & 9031,8 & 12603,8 & 11528,6 & 12238,2 & 14101,8 \\
\hline $\begin{array}{l}\text { Investment volume to the } \\
\text { Ukrainian economy }\end{array}$ & 78,4 & 86,1 & 35,6 & 66,0 & 52,1 & 61,4 & 0,9 & 31,9 & 99,0 & 1131,8 \\
\hline Securities & 10968,5 & 13148,6 & 13079,3 & 33942,1 & 21334,1 & 22677,0 & 15279,4 & 14452,3 & 14212,2 & 13968,7 \\
\hline $\begin{array}{l}\text { Investment volume on the } \\
\text { one IC, UAH million }\end{array}$ & 42,40 & 48,17 & 53,18 & 108,61 & 80,29 & 88,63 & 83,48 & 92,44 & 99,52 & 114,83 \\
\hline \multicolumn{11}{|c|}{ Non-government pension founds } \\
\hline Number of NPF & 108 & 101 & 96 & 94 & 81 & 76 & 72 & 64 & 64 & 62 \\
\hline Assets of NPF, UAH million & 834,0 & 1108,6 & 1349,8 & 1660,0 & 2089,8 & 2469,2 & 1980,0 & 2138,7 & 2465,6 & 2745,2 \\
\hline $\begin{array}{l}\text { Investment volume } \\
\text { of NPF, includes, UAH } \\
\text { million: }\end{array}$ & 780,0 & 1051,2 & 1302,0 & 1570,8 & 2011,4 & 2358,0 & 1873,1 & 2071,7 & 2374,6 & 2648,2 \\
\hline Bank deposits & 343 & 396,8 & 409,8 & 527,7 & 760,2 & 953,8 & 780,7 & 884,2 & 1083,3 & 985,5 \\
\hline Securities & 386,7 & 558,1 & 817,5 & 974,9 & 1178,5 & 1319,8 & 1006,7 & 1092,8 & 1218,6 & 1605,9 \\
\hline Real estate & 18,2 & 64,6 & 48,6 & 49,6 & 58 & 69,9 & 72,2 & 86,0 & 62,6 & 47,3 \\
\hline Precious metals & 32,1 & 31,7 & 26,1 & 18,6 & 14,7 & 14,5 & 13,5 & 8,7 & 10,1 & 9,8 \\
\hline $\begin{array}{l}\text { Investment volume on the } \\
\text { one NPF, UAH million }\end{array}$ & 7,2 & 10,4 & 13,6 & 16,7 & 24,8 & 31,0 & 26,01 & 32,4 & 37,1 & 42,7 \\
\hline
\end{tabular}

The specifics of the IC's activities lead to different approaches to investing. Life insurance companies typically invest in long-term investment instruments because their income exceeds insurance premiums and expenses, and the latter can be paid from premium and investment income. Therefore, it is inappropriate to use short-term securities as investment instruments. For risk insurance companies, the availability of money to pay insurance compensation is usually of primary importance. However, this requires that investments be made relatively quickly so that they can be easily converted into money when needed.
The study showed that the main source of income for the IC in most developed countries is not the collection of insurance payments, but the very investment activities, which income is spent, as a rule, to finance insurance operations, subsidies for loss-making insurance, new product development, staff training. However, the opposite is in Ukraine, meaning that ICs are reluctant to invest in various innovative projects as these investments are considered to be very risky.

For investing purposes, IC should use (Yavorska, 2012): 
- equity, thus helping to form tangible, intangible, and financial assets. The investment of such funds in Ukraine is not regulated by law and is carried out by the IC at its own discretion, but with some exceptions: the regulation of financial investments in corporate rights;

- insurance reserves funds, whose investment is regulated by the law. Insurance reserve funds are invested into assets characterized by a high level of liquidity so that, at any point in time, the IC can fulfill its obligations to insurers to pay insurance compensation.

\section{RESULTS}

ICs in Ukraine use financial assets such as bank deposits, real estate, investments in the economy, securities, banking metals, loans to insurers, and long-term housing loans for investment purposes. Traditionally, domestic banks invest the lion's share of their funds in bank deposits, as their investment attractiveness is caused by rather high liquidity and a guaranteed return. Life insurance companies may invest not more than $70 \%$ of their total insurance reserves in deposits. When investing in deposits the IC does not involve professional intermediaries and does not spend much time (the terms of the deposit agreement are standard), and what is the most important is that the bank is a profitable partner on the financial market where insurance services, credit risk insurance, in particular, are offered. In turn, the bank where the investment funds are placed must have a credit rating that corresponds to the investment level on a national scale (Rekunenko \& Chorna, 2017). However, this requirement is not always met by the ICs, considering that only some banks have this rating.

It can be seen in Table 1 that for over the nine years, IC's investment in deposits has almost tripled (2009: UAH 5,926.4 million, 2018: UAH 14101.8 million). Investments in the Ukrainian economy exceeded all analysts' forecasts and, in 2018, reached UAH 1,131.8 million, which is 15 times higher than in 2009. However, in 2015, the IC did not show any interest in this investment asset (UAH 0.9 million), due to the economic and political situation in Ukraine and the war in the
East. One should pay special attention to the securities, whose volumes gradually increased during the study period, reaching the highest volumes in 2012 - UAH 33942.1 million. After that, they began to decline actively and at the end of 2018 amounted to UAH 13,968.7 million, reaching the level of 2011 (the bulk of investments are made each year on shares and securities issued by the state; but at the same time, IC refuse to invest in mortgage certificates already for the third year in a row, due to their low investment attractiveness and not significant income). These three investment assets are presented in Table 1, and they have been selected on the principle of the most profitable and those which possess a share of $70-90 \%$ in the IC's assets.

It should be emphasized that the share of precious metals in the investment component of IC is almost negligible (UAH 32.2 million in 2018). The inclusion of gold in the investment portfolio can be useful for increasing the risk-adjusted return on the investment portfolio. An important characteristic of gold as an asset class is that it does not act as a liability, like all debt securities, and does not certify the claim on its assets in the form of shares. Therefore, investors in gold do not carry bankruptcy risk, unlike investors in any securities.

When talking about real estate investments (for the period under review, they increased by half from UAH 1997.8 million in 2009 to UAH 3014 million in 2018), it can be seen that real estate investment typically provides a higher return than the loan facility. Due to the increase in the share of these assets, significant investments could be made in the housing sector, which is especially attractive for long-term insurance companies.

Thus, Ukraine's investment opportunities of the ICs are not used sufficiently. Often, having a remuneration for participating in the shadow business, ICs do not invest actively; it is considered minor, and in case it is implemented, it is only short-term in highly liquid but low-income instruments.

NPFs, accumulating participants' cash in the form of pension contributions and pledging to increase them by investing in financial instruments, are institutional investors characterized by the characteristics that determine their investment activities: 
- have a non-business status, so they cannot be engaged in activities other than accumulating pension contributions, investing them and making pension payments;

- may invest retirement funds according to the established restrictions for the long-term or medium-term period (the specific list of NPF assets, the limits of their investment, directions of use, and the procedure for managing the assets are defined);

- distribute the profit received from investing among the fund members in proportion to the funds in their accounts, making it impossible to use the funds for the commercial purposes of its immediate founders;

- minimize risks by distributing funds between a large number of investment instruments, which guarantees a stable investment income and the reliability of future pension payments;

- financial investment of assets prevails, limited ability to form a portfolio of NPF real investments;

- investment instruments must be constantly reviewed in accordance with the changing market conditions, and the proportion of non-investment resources (current account costs and receivable accounts) in the total asset structure is limited to $5 \%$ by law.

NPFs started operating in Ukraine in 2005. Their number was 54 institutions. There was a tendency to increase the number of NPFs in the following years, and in 2009 the State Register of Financial Institutions added information about 108 NPFs. The quantitative characteristics of NPF development in 2009-2018 are presented in Table 1. During the mentioned period there is decreasing a tendency in the number of NPFs: from 108 in 2009 to 62 in 2018, which is due, first of all, to the consequences of the financial and economic crisis and the levels of socio-economic development of Ukraine as well as the political situation and the situation in the East of the country.

The majority of NPFs in Ukraine are created in the form of an open joint-stock company, which is explained by greater transparency and their accessibility to the population. At the same time, the members of professional and corporate NPFs can be only natural persons linked by their professional activity or in labor relations with employers-founders or employers-payers (Shaliyevska, 2018).

The investment activity of the NPF is formed not as a result of investment into the development of the national economy, agriculture, or industry in particular. The purpose of investing pension assets is, first and foremost, to preserve citizens' retirement savings, so NPFs as investors are more conservative than other non-bank financial institutions. The prevailing directions and objects for pension assets investing are deposits with banks, bonds of enterprises, the issuers of which are residents of Ukraine; shares of Ukrainian issuers, securities, and the income guaranteed by the Cabinet of Ministers of Ukraine. The detailed structure of invested pension assets for the period 2009-2018 is presented in Table 1.

The investment instruments of NPFs in the general structure for the analyzed period are distributed and characterized by the following features:

- the volume of investments placed on bank deposits tends to increase. At the same time, this investment instrument is characterized by increased risks of financial instability, in particular, due to the non-repayment of pension assets placed in the deposit accounts of several banking institutions where a temporary administration has been introduced or a decision to eliminate them has been taken;

- the share of securities used for investing by NPFs is the largest, in particular: the volume of investments in securities, which income is guaranteed by the Cabinet of Ministers of Ukraine; since 2010 there have not any mortgage securities in the investment portfolio of NPFs, and in 2009 their share was negligible $-0.05 \%$.

- the share of investments in real estate and precious metals is insignificant;

- the share of NPF investments in the country's GDP is very small, the level of return on pen- 
sion assets is not high, and the list and choice of financial instruments that can be used to invest pension contributions of non-state pension funds are limited. The procedure for accessing NPFs to external financial markets (to foreign investors) is complicated, as evidenced by the absence of foreign securities in the investment portfolios of the NPFs;

- the limited choice of financial instruments, which are defined by the legislation, partially meets the requirements of NPFs (bonds of internal state loan, stocks, and bonds of enterprises, savings certificates, bank deposits) due to the lag of capital market development;

Thus, the long-term nature of retirement savings and their social orientation objectively determine the need for long-term and reliable financial services as investment assets for retirement assets with the proper security of liabilities under these financial instruments.

Having analyzed and identified the peculiarities of the investment instruments of the three financial intermediaries in Ukraine, the authors will create trend models for evaluating the trends of investment development and forecasting the development of their activity.

It should be noted that different approximation functions can be selected to construct a trend line.
An analysis of the approximation parameters allows choosing the function that best describes the researched time range and reflects trends.

The created trend model of the investment volume of Ukrainian banks is presented in Figure 1. The coefficient of determination $R^{2}=0.98$ and other indicators of regression statistics (coefficient of multiple correlation and normalized $R^{2}$ ) indicate the adequacy of the constructed model and the possibility of its use for predicting the researched indicator.

Similarly, the trend model of investment activity of ICs and NPFs, which is shown in Figure 2 and based on a third-order polynomial trend, was created.

The coefficient of determination $R^{2}=0.56$ and other indicators of regression statistics reveal the almost perfect shape of the created model and the possibility of its use to predict the investment activity of the IC with the simultaneous analysis of the influence of other factors.

The coefficient of determination $R^{2}=0.96$ and other regression statistics indicate an adequately constructed model and the possibility of predicting NPF investment.

Let us analyze in more detail the forecasting investment models of financial institutions. Estimated

Source: Created by the authors of the article based on statistics of Ukraine (official data of insurance companies in 2012-2018, official activity data of banks in 2009-2018, results of the development of the private pension system in 2011-2018).

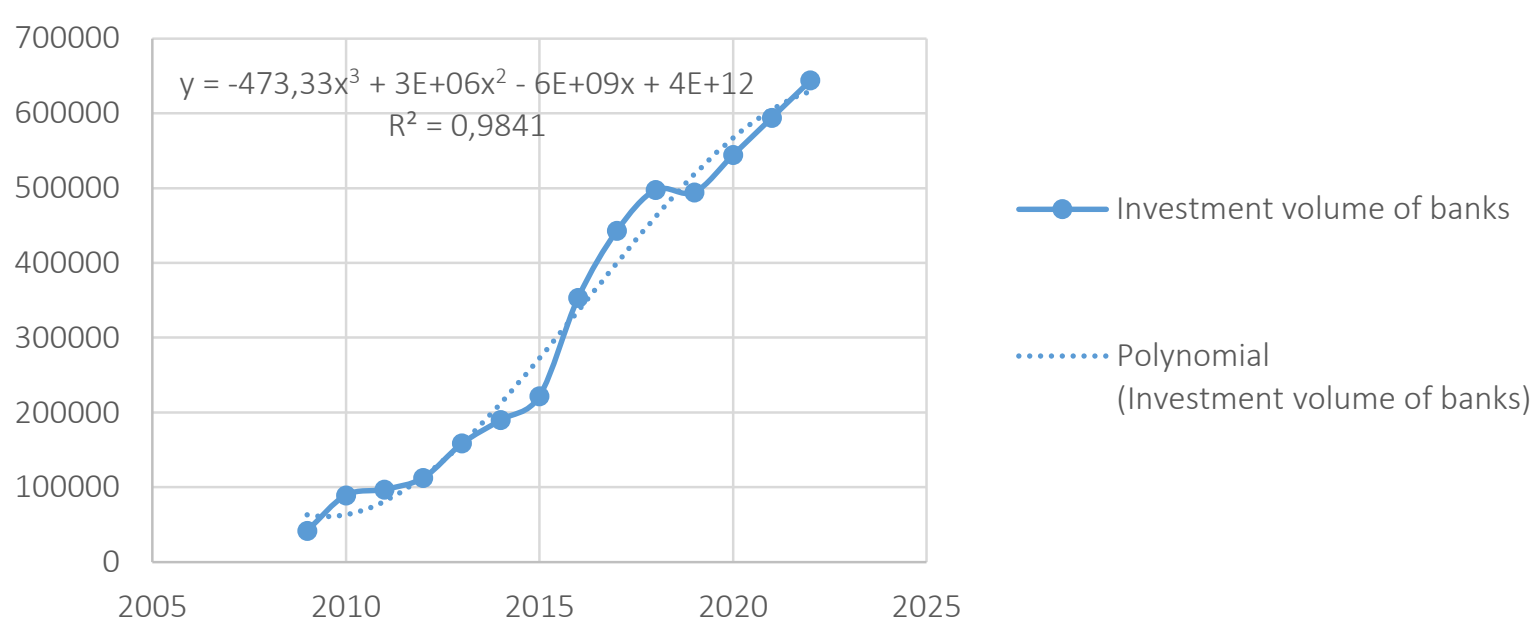

Figure 1. Trend model of investment volume of Ukrainian banks 
Source: Created by the authors of the article based on statistics of Ukraine (official data of insurance companies in 2012-2018, official activity data of banks in 2009-2018, results of the development of the private pension system in 2011-2018).

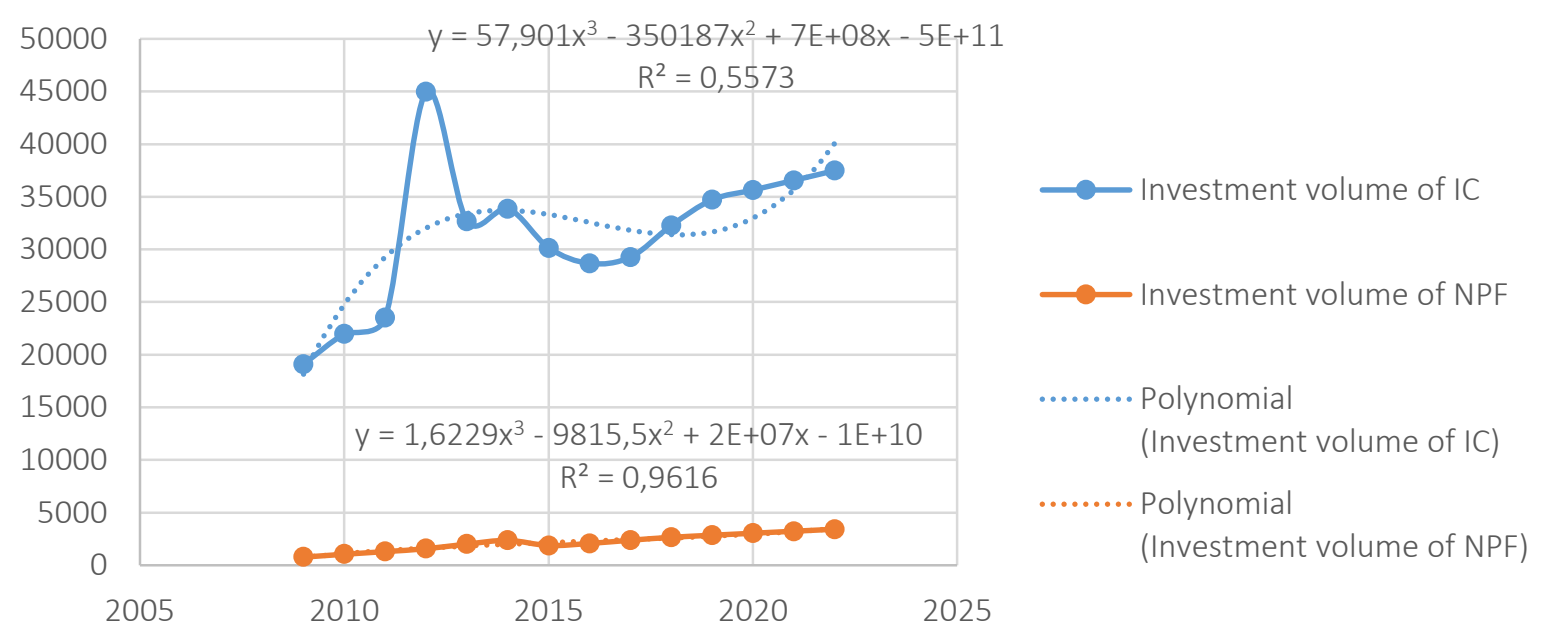

Figure 2. Trend model of investment volume of IC and NPF

forecasts of investment volumes of banks, ICs, and NPFs, are presented in Table 2 and Figure 3.

Table 2. Results of basic parameters forecast

\begin{tabular}{|c|c|c|c|}
\hline Year & $\begin{array}{c}\text { Bank } \\
\text { investment } \\
\text { forecast }\end{array}$ & $\begin{array}{c}\text { NPF } \\
\text { investment } \\
\text { forecast }\end{array}$ & $\begin{array}{l}\text { Investment } \\
\text { forecast of } \\
\text { the IC }\end{array}$ \\
\hline 019 & 494470,3 & 2843,5 & 34708,9 \\
\hline 2020 & 544272,4 & 3032,5 & 35631,1 \\
\hline 2021 & 594074,5 & 3221,5 & 36553,3 \\
\hline 022 & 643876,6 & 3410,5 & 37475,5 \\
\hline
\end{tabular}

When looking at the volume of investments of banks of Ukraine in 2009-2018, one can see that they increased more than 11 times during the researched period. As for other financial intermediaries, the development of their investment activities is not so rapid. Thus, the volume of investment of NPFs in 2018 increased more than three times compared with 2009, and the investment activity of the ICs grew during the analyzed period by only $72 \%$.

In accordance with the forecast model of the volume of investments of Ukrainian banks in 2022, the size of investments will amount to UAH 643877 million; that is, they will increase by $29 \%$ compared with 2018.
The development of the investment activity of the IC during 2009-2018 was ambiguous. Thus, in 2009-2012, there was an increase in the volume of investments and in 2012 their volume made maximum in the researched period and amounted to UAH 44963 million, and in 2013 the decrease of investment activity of the IC started, which lasted until 2016 and amounted to UAH 28656 million. Since 2016, ICs have begun to increase their investment activity and, in 2018, reached practically the level of 2013 with the amount of UAH 32266.2 million. However, in the forecast period, there is an increase in the volume of investments of the ICs, and in 2022 it will amount to UAH 37476 million.

During 2009-2018, the volume of investments of NPFs grew dynamically with certain regularities. Thus, in 2009-2014 there was an increase in the volume of investments in steps of approximately UAH 300 million, and in 2015 their volume decreased by almost UAH 500 million and amounted to UAH 1873.1 million. In 2016 the volume of investment activity of NPFs began to increase and in 2018 reached its maximum in the researched period, which amounted to UAH 2648.2 million. In the forecast period, there is an increase in the volume of investments of NPFs, so in 2022 it will amount to UAH 3410.5 million.

In general, the created trend models indicate the development of major financial intermediaries' in- 
Source: Created by the authors of the article based on statistics of Ukraine (official data of insurance companies in 2012-2018, official activity data of banks in 2009-2018, results of the development of the private pension system in 2011-2018).

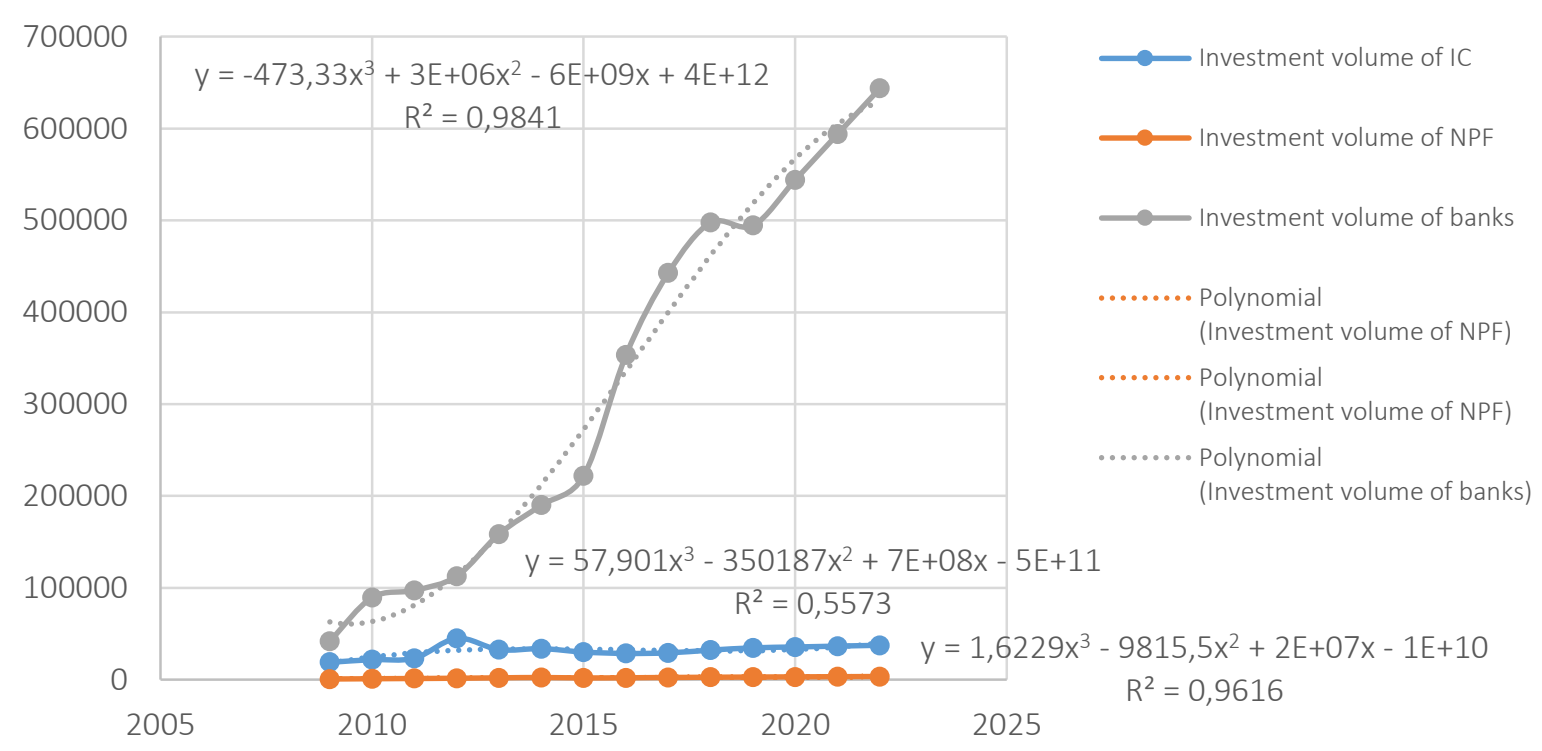

Figure 3. Forecasting the volume of investment by financial intermediaries for $2020-2022$

vestment activity. The pace of their development is different, due to both the influence of various factors and tendencies as well as directions of their investment activities.

Considering the spread of the COVID-19 pandemic, it is currently impossible to predict its impact on the investment activity trends of the major financial business entities of Ukraine. This is due to the following factors: the basis for the forecast trends development is not monthly or quarterly, but annual official statistics; the duration of the pandemic is only 2-3 months; the investment activity of Ukrainian banks, ICs and NPFs is still very poorly integrated into the global financial market, and the share of the proceeds from their investment activities in the external financial market is insignificant.

\section{CONCLUSION}

The issue of the investment activities development of financial intermediaries in Ukraine cannot be left unnoticeable by the state, which should create conditions for intensifying their investment activity and preventing the outflow of funds outside the country. Moreover, the more stable, transparent, and clearer the legislation in this area is, the more protected the interests of financial intermediaries. Political and economic instability in Ukraine has a negative impact on the investment climate, on the investment activities of financial intermediaries in particular. To ensure a favorable investment climate is a strategic task so far because it depends on the development of Ukraine's economy.

To increase banks' investment activity, it is necessary to solve the problem of their capitalization, which is relevant for the vast majority of banks, and only then create favorable conditions for investment activities in general. To develop the banks' investment activity, the most important steps have been taken to improve the management of their investment component. The analysis of investment trends of Ukrainian insurance companies showed that investment activity demonstrates an insufficient implementation of the investment function of insurance, which is manifested in the structural features and return on investment. The intensification of insurance companies' investment activity will contribute to the development of Ukraine's investment climate, ensuring which should become a priority shortly. To 
intensify the investment activity of domestic NPFs, it is necessary to extend the rate by which NPFs are allowed to invest only in those government securities, which are secured by assets.

\section{AUTHOR CONTRIBUTIONS}

Conceptualization: Tetyana Yavorska.

Data curation: Lyudmyla Voytovych, Tetyana Yavorska, Olesya Irshak.

Formal analysis: Lyudmyla Voytovych, Olesya Irshak.

Funding acquisition: Lyudmyla Voytovych, Serhiy Reverchuk, Tetyana Yavorska, Olga Vovchak.

Investigation: Lyudmyla Voytovych.

Methodology: Serhiy Reverchuk.

Project administration: Serhiy Reverchuk.

Resources: Lyudmyla Voytovych, Tetyana Yavorska.

Software: Olesya Irshak.

Supervision: Olga Vovchak.

Validation: Serhiy Reverchuk, Olga Vovchak.

Visualization: Tetyana Yavorska.

Writing - original draft: Lyudmyla Voytovych, Tetyana Yavorska.

Writing - review \& editing: Lyudmyla Voytovych.

\section{REFERENCES}

1. Della Croce, R. (2011). Pension Funds Investment inInfrastructure: Policy Actions (OECD Working Papers on Finance, Insurance and Private Pensions). http://dx.doi. org/10.1787/5kg272f9bnmx-en

2. Denysenko, M. P., \& Tokacheva, A. V. (2018). Investytsiina diialnist strakhovoi kompanii: problemy ta napriamy aktyvizatsii [Investment activity of an insurance company: problems and directions of activation]. Efektyvna ekonomika - Effective economics, 10, 1-7. (In Ukrainian). Retrieved from http:// www.economy.nayka.com.ua/ pdf/10_2018/11.pdf

3. Gordillo, P. M. (2019). Eight key concepts you should know about investment banking. Retrieved from https://www.bbva.com/en/ eight-key-concepts-you-shouldknow-about-investment-banking/

4. Kichurchak, M. (2019). Bankivska depozytna diialnist $\mathrm{v}$ napriamku Ukrainy ta fakty aktyvizatsii rozvytku [Bank deposit activity in Ukraine direction and factors of development activation]. Journal of Eastern European and Central Asian Research (JEECAR), 1, 145160. (In Ukrainian)
5. Kuzheliev, M. O. (2016). Finansova hnuchkist pryiniattia rishen $v$ investytsiinii diialnosti bankiv [Financial flexibility of decision-making in the investment activity of banks]. Kyiv: "Tsentr uchbovoi literatury". (In Ukrainian). Retrieved from https://www.yakaboo.ua/finansova-gnuchkist-prijnjattja-rishenv-investicijnij-dijal-nosti-bankiv. html

6. Kvasnytska, R. S. (2014). Banky yak investory na finansovomu rynku: rol ta status [Banks as investors in the financial market: role and status]. Finansovyi prostir - Financial space, 3(15), 116-119. (In Ukrainian). Retrieved from https://fp.cibs.ubs.edu.ua/index. $\mathrm{php} / \mathrm{fp} /$ article/view/290

7. Liaw, K. T. (2012). The Business of Investment Banking. A Comprehensive Overview (3rd ed.). Wiley: Hoboken, NJ. Retrieved from https://www.questia.com/ $\mathrm{read} / 123789102 /$ the-business-ofinvestment-banking-a-comprehensive

8. Marchenko, O. V. (2017). Otsinka kredytno-investytsiinoi diialnosti banku [Assessment of the bank's investment activity]. Molodyi vchenyi - Young scientist, 2(42), 283-287. (In Ukrainian)

9. Ministry of Finance of Ukraine. (n.d.). Statystychni dani po osnovnykh pokaznykakh bankiv $v$ Ukraini. [Statistics on the main indicators of banks in Ukraine]. (In Ukrainian). Retrieved from https:// minfin.com.ua

10. Ministry of Finance of Ukraine. (n.d.). Statystychni dani po rynku strakhuvannia $v$ Ukraini [Statistics on the insurance market in Ukraine]. (In Ukrainian). Retrieved from https://minfin.com. ua/ua/insurance/

11. National Bank of Ukraine. (n.d.). Ofitsiini dani diialnosti bankiv u 2009-2018 rr. [Official activity data of banks in 2009-2018]. (In Ukrainian). Retrieved from https:// bank.gov.ua/statistic/sector-financial/data-sector-financial\#1ms

12. National Bank of Ukraine. (n.d.). Ofitsiini dani diialnosti strakhovykh kompanii u 2012-2018 rr. [Official data of insurance companies in 2012-2018]. (In Ukrainian). Retrieved from https://www.nfp. gov.ua/ua/Informatsiia-pro-stani-rozvytok-strakhovoho-rynkuUkrainy.html 
13. NFP. (2009). Pidsumky rozvytku systemy nederzhavnoho pensiinoho zabezpechennia za $2009 \mathrm{r}$. [Results of the development of the nonstate pension system for 2009]. (In Ukrainian).

14. NFP. (2011). Pidsumky rozvytku systemy nederzhavnoho pensiinoho zabezpechennia za $2011 \mathrm{r}$. [Results of the development of the private pension system for 2011]. (In Ukrainian). Retrieved from https://www.nfp.gov.ua/files/OgliadRinkiv/NPF/npz_2011.pdf

15. NFP. (2012). Pidsumky rozvytku systemy nederzhavnoho pensiinoho zabezpechennia za 2012 r. [Results of the development of the private pension system for 2012]. (In Ukrainian). Retrieved from https://nfp.gov.ua/files/OgliadRinkiv/NPF/npz-2012r.pdf

16. NFP. (2014). Pidsumky rozvytku systemy nederzhavnoho pensiinoho zabezpechennia stanom na 31.12.2014 $r$. [Results of the development of the private pension system as of December 31, 2014]. (In Ukrainian). Retrieved from https://www.nfp.gov.ua/ua/ Informatsiia-pro-stan-i-rozvytoknederzhavnoho-pensiinoho-zabezpechennia-Ukrainy.html

17. NFP. (2015). Pidsumky rozvytku systemy nederzhavnoho pensiinoho zabezpechennia stanom na 31.12.2015 r. [Results of the development of the private pension system as of December 31, 2015]. (In Ukrainian). Retrieved from https://www. nfp.gov.ua/files/sektor/NPF_ IV\%D0\%BA\%D0\%B2_2015.pdf

18. NFP. (2016). Pidsumky rozvytku systemy nederzhavnoho pensiinoho zabezpechennia stanom na 30.09.2016 r. [Results of the development of the private pension system as of September 30, 2016]. (In Ukrainian). Retrieved from https://www.nfp.gov.ua/files/17 Dep_Repetska/NPF_IV_kv\%20 2016.pdf

19. NFP. (2017). Pidsumky rozvytku systemy nederzhavnoho pensiinoho zabezpechennia stanom na 31.12.2017 r. [Results of the development of the private pension system as of December 31, 2017].
(In Ukrainian). Retrieved from https://www.nfp.gov.ua/files/17 Dep_Repetska/NPF_IV_kv\%20 2017.pdf

20. Onyshchenko, Ju. I. (2018). Upravlinnia investytsiinoiu diialnistiu banku: teoriia ta praktyka [Bank Investment Management: Theory and Practice]. Infrastructura rynku Market infrastructure, 25, 738-744. (In Ukrainian). Retrieved from http://dspace.oneu.edu.ua/jspui/ handle/123456789/10411

21. Rekunenko, I. I., \& Chorna, S. V. (2017). Osoblyvosti investytsiinoi diialnosti strakhovykh kompanii. [Features of investment activity of insurance companies]. Ekonomika $i$ suspilstvo - Economy and society, 8, 666-672. (In Ukrainian). Retrieved from http://www. economyandsociety.in.ua/journal/8_ukr/111.pdf

22. Shaliyevska, L. I. (2018). Vplyv destruktyvnykh chynnykiv na rozvytok nederzhavnoho pensiinoho zabezpechennia $\mathrm{v}$ Ukraini [Impact of destructive factors on the development of non-state pension provision in Ukraine]. Prychornomorski ekonomichni studii - North Sea economic studies, 36, 118-122. (In Ukrainian)

23. Verkhovna Rada of Ukraine. (2017). Plan zakhodiv iz zaprovadzhennia nakopychuvalnoi systemy zahalnooboviazkovoho derzhavnoho pensiinoho strakhuvannia na 2017-2018 rr.: Rozporiadzhennia Kabinetu Ministriv Ukrainy № 723-r vid 11.10.2017 r. [Plan of measures for introduction of the cumulative system of compulsory state pension insurance for 20172018: Order of the Cabinet of Ministers of Ukraine No. 723-p of 11.10.2017]. (In Ukrainian). Retrieved from https://zakon. rada.gov.ua/laws/show/723-2017$\% \mathrm{D} 1 \% 80$

24. Vovchak, O., Reverchuk, S., Rudevska, V., \& Khlan, Ya. (2019). Modeliuvannia bankivskoho biznesu ta rivni neefektyvnykh pozyk: perspektyvy mizhnarodnykh faktoriv ryzyku v Ukraini [Bank business modeling and levels of nonperforming loans: perspectives of international risks factors in Ukraine]. Journal of Eastern European and Central Asian Research (JEECAR), 1, 282296. (In Ukrainian). https://doi. org/10.15549/jeecar.v6i2.391

25. Yavorska, T. V. (2012). Derzhavne rehuliuvannia strakhovoho pidpryiemnytstva $v$ Ukraini [State regulation of insurance business in Ukraine]. Lviv: LNU imeni Ivana Franka. (In Ukrainian) 